Int. J. Dev. Biol. 52: 585-594 (2008)

doi: $10.1387 / \mathrm{ijdb} .072530 \mathrm{ks}$

\title{
The dynamics of calcium oscillations that activate mammalian eggs
}

\author{
KARL SWANN* and YUANSONG YU \\ Department of Obstetrics and Gynaecology, School of Medicine, Cardiff University, Cardiff, UK
}

\begin{abstract}
It has been known for some time that mammalian eggs are activated by a series of intracellular calcium oscillations that occur shortly after sperm egg membrane fusion. Recent work has identified a novel sperm specific phospholipase $C$ zeta as the likely agent that stimulates the calcium oscillations in eggs after sperm-egg membrane fusion. PLCzeta is stimulated by low intracellular calcium levels in a manner which suggests that there is a regenerative feedback of calcium release and PLCzeta induced inositol 1,4,5-trisphophate $\left(\operatorname{lns} \mathrm{P}_{3}\right)$ production in eggs. This implies calcium oscillations in fertilizing mammalian eggs are driven by underlying oscillations of Ins $\mathrm{P}_{3}$. This model of oscillations is supported by the response of mouse eggs to sudden increases in Ins $P_{3}$. The cellular targets of calcium oscillations include calmodulin-dependent protein kinases, protein kinase $C$ and mitochondria. There is evidence that eggs might be best activated by multiple calcium increases rather than a single calcium rise. As yet we do not fully understand how the target of calcium in a mammalian egg might decode the patterns of calcium changes that can occur during egg activation.
\end{abstract}

KEY WORDS: fertilization, egg, sperm, calcium, oscillations

\section{Introduction}

At fertilization the egg is activated to begin development. Egg activation can involve a multitude of cellular changes depending upon the species. The most widely observed changes in mammals are the completion of meiosis, the exocytosis of cortical granules, changes in the pattern of protein synthesis and the formation of pronuclei indicating the start of the first zygotic cell cycle (Ducibella et al., 2006; Stricker, 1999; Runft et al., 2002; Whitaker 2006). A role for $\mathrm{Ca}^{2+}$ in directly causing the events egg activation at fertilization was first indicated when it was reported that application of this $\mathrm{Ca}^{2+}$ ionophore, to causes a rise in cytosolic $\mathrm{Ca}^{2+}$, was able to induce the early events of activation in eggs of a wide range of species including those from hamsters (Steinhardt et al., 1974). Subsequently, it was also shown that microinjection of $\mathrm{Ca}^{2+}$ ions alone could trigger embryo development up to the blastocyst stage in the mouse (Fulton and Whittingham, 1978). The importance of $\mathrm{Ca}^{2+}$ changes was then later demonstrated by showing that chelation of $\mathrm{Ca}^{2+}$ ions using BAPTA could block all signs of activation in mouse eggs (Kline and Kline, 1992a). These data suggest that a $\mathrm{Ca}^{2+}$ increase in the egg is a universal trigger for the activation of development in mammals. The first measurements of $\mathrm{Ca}^{2+}$ at fertilization were in medaka fish eggs, and then sea urchin eggs, where the $\mathrm{Ca}^{2+}$ sensitive photoprotein aequorin was used to show that a wave of cytosolic free $\mathrm{Ca}^{2+}$ increase crosses the egg after sperm interaction (Ridgway et al., 1977; Steinhardt et al., 1977). These studies suggested that a single $\mathrm{Ca}^{2+}$ increase that lasts several minutes is the cause of egg activation in these species.

In 1981 two papers were published that suggested that the free $\mathrm{Ca}^{2+}$ changes in mammalian eggs might be more complex than in fish or sea urchin eggs. Firstly measurements of the membrane potential in fertilizing hamster eggs showed a series of repetitive hyperpolarizations within 10 seconds of sperm egg interaction (Igusa and Miyazaki 1981). Since the hyperpolarizations appeared to be due to a $\mathrm{Ca}^{2+}$-activated $\mathrm{K}^{+}$conductance the data suggested that hamster eggs underwent period $\mathrm{Ca}^{2+}$ changes at fertilization (Igusa and Miyazaki, 1982). Other studies using aequorin to measure $\mathrm{Ca}^{2+}$ directly also suggested that fertilization in mouse eggs was accompanied by periodic increases in cytosolic free $\mathrm{Ca}^{2+}$ (Cuthberston et al., 1981; Cuthbertson and Cobbold, 1985). These data in mouse and hamster eggs were backed up

Abbreviations used in this paper: $\mathrm{InsP}_{3}$, inositol triphosphate; PLC, phospholipase

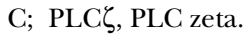

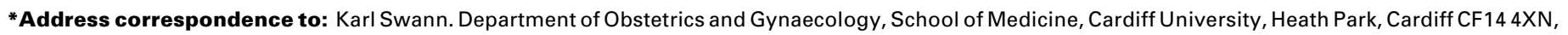
U.K. Fax: +44-2920-744399. e-mail: Swannk1@Cardiff.ac.uk
}

Published online: 30 May 2008

0214-6282/2008/\$35.00

(C) UBC Press

Printed in Spain 
by further studies which confirmed that a series of repetitive $\mathrm{Ca}^{2+}$ oscillations occurred for several hours following sperm egg interaction. Studies in many other mammalian species using fluorescent dyes to measure $\mathrm{Ca}^{2+}$ have subsequently confirmed that a prolonged series of $\mathrm{Ca}^{2+}$ oscillations with a wavelike onset is a characteristic feature of mammalian egg fertilization (Miyazaki et al., 1993). Fig. 1A shows an example of a mouse egg undergoing $\mathrm{Ca}^{2+}$ oscillations at fertilization.

We now know that $\mathrm{Ca}^{2+}$ oscillations are not unique to mammalian eggs since fertilizing ascidian oocytes also demonstrate a series of $\mathrm{Ca}^{2+}$ oscillations at fertilization (Dumollard et al., 2004a). However, the response in mammalian eggs is distinctive in that the oscillations lasts for several hours and involve relatively low frequency, large amplitude $\mathrm{Ca}^{2+}$ increases. The mechanism and consequences of these $\mathrm{Ca}^{2+}$ oscillations is pivotal for our understanding of how a sperm activates development. This review will focus on the dynamic aspects of $\mathrm{Ca}^{2+}$ signalling and discuss how oscillations are generated, and how they may be transformed into a response by the egg. Some of the potential downstream targets of $\mathrm{Ca}^{2+}$ signals in eggs, such as myosin light chain kinase, or src family protein kinases (Matson et al., 2006; McGinnis et al., 2007), are not discussed since there is no explicit dynamic data on their activity at fertilization.

\section{$\mathrm{Ca}^{2+}$ release at fertilization in mammalian eggs is gen- erated by $\operatorname{lns} \mathrm{P}_{3}$ production}

The $\mathrm{Ca}^{2+}$ oscillations in mammalian eggs appear to be a result of $\mathrm{Ca}^{2+}$ release via the $\mathrm{InsP}_{3}$ receptor (predominantly type 1 ) that is both the receptor for $\operatorname{lns}_{3}$ and $\mathrm{a} \mathrm{Ca}^{2+}$ release channel (Kurakawa et al., 2004). Studies in mouse and hamster eggs demonstrated that blocking the $\operatorname{Ins}_{3}$ receptor with a specific antibody inhibits $\mathrm{Ca}^{2+}$ oscillations at fertilization (Miyazaki et al., 1993). Furthermore, injecting adenophostin to cause the down-regulation of Ins $\mathrm{P}_{3}$ receptors before fertilization, can block all $\mathrm{Ca}^{2+}$ oscillations in subsequently fertilized eggs (Brind et al., 2000; Jellerette et al., 2000). Reducing the expression of Ins $\mathrm{P}_{3}$ receptors by injection of siRNA can also inhibit subsequent $\mathrm{Ca}^{2+}$ oscillations in fertilizing mouse eggs (Xu et al., 2003). Other $\mathrm{Ca}^{2+}$ releasing agents such as cyclic ADP ribose, nitric oxide or NAADP do not appear to cause $\mathrm{Ca}^{2+}$ release in mouse eggs and so other $\mathrm{Ca}^{2+}$ release channels are probably not directly involved in generating $\mathrm{Ca}^{2+}$ oscillations. These data all show that that the $\operatorname{lns}_{3}$ receptor is the essential messenger for $\mathrm{Ca}^{2+}$ release in mammalian eggs fertilization.

The essential role of the $\operatorname{lns} \mathrm{P}_{3}$ receptor implies that increased Ins $\mathrm{P}_{3}$ production occurs at fertilization in eggs. Increases in phosphoinositide turnover and Ins $_{3}$ production have been demonstrated from biochemical and radiolabelling assays in sea urchin and frog eggs (Whitaker, 2006). However, this is impractical in mammalian eggs because thousands of eggs are required. However, a useful probe for measuring InsP $_{3}$ production in single cells is GFP (green fluorescent protein) tagged to the $\mathrm{PH}$ (pleckstrin homology) domain of PLC $\delta 1$ (Hirose et al., 1999). The translocation of this probe away from the phosphatidyl-inositol bisphosphate $\left(\mathrm{PIP}_{2}\right)$ in plasma membrane into the cytoplasm can be caused by increase Ins $_{3}$ production and so this translocation can be used to indicate InsP $_{3}$ production (Hirose et al., 1999). When introduced into mouse eggs the GFP-PH domain this probe under-

\section{A Fertilization}

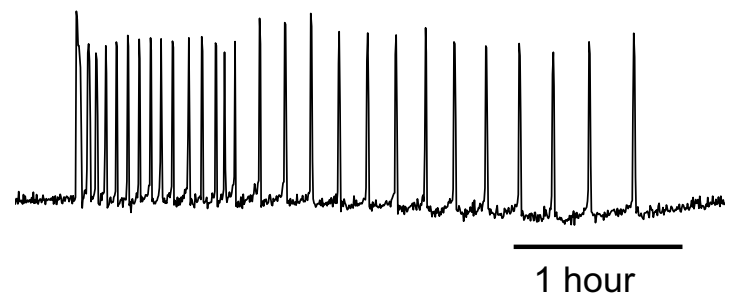

B Injection of PLC $\zeta$

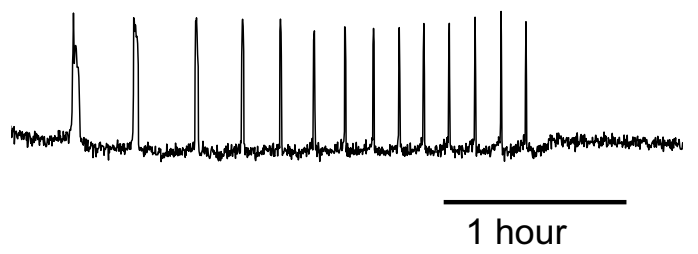

Fig. 1. Intracellular $\mathrm{Ca}^{2+}$ oscillations in mouse eggs measured by the fluorescence of a $\mathrm{Ca}^{2+}$ sensitive dye (Oregon green BAPTA dextran). See Campbell and Swann (2006) for experimental details. In (A), an egg is shown in response to fertilization, and in (B), the response of an egg is shown after microinjection of CRNA for mouse PLCY (Campbell and Swann, 2006; Saunders et al., 2002). The fluorescence F on the $y$-axis is in arbitrary units, so the $\mathrm{Ca}^{2+}$ levels are not calibrated.

goes an increase in plasma membrane labelling with each of the early $\mathrm{Ca}^{2+}$ increases (Halet et al., 2002). This is paradoxical since, if fertilization triggers an increase in Ins $_{3}$ production, the probe would be expected to detach from the plasma membrane and translocate to the cytosol. In fact the data suggest that the probe does not respond to InsP $_{3}$ changes in mouse eggs, but instead this probe is relocating due to an increase in $\mathrm{PIP}_{2}$ in the plasma membrane (Halet et al., 2002).

Although it has proved difficult to use fluorescent $\operatorname{lns}_{3}$ indicators in fertilizing mouse eggs (but see later), sperm induced InsP production in mammalian eggs can be inferred from the finding that fertilization leads to a marked down-regulation in the number of InsP $\mathrm{P}_{3}$ receptors (Brind et al., 2000; Jellerette et al., 2000). This down-regulation is not due to the $\mathrm{Ca}^{2+}$ increase and can only be induced by agents that bind to the $\operatorname{InsP}_{3}$ receptor on the $\operatorname{InsP}_{3}$ binding site. This data clearly suggest that $\operatorname{lns} \mathrm{P}_{3}$ does increase at fertilization in mammalian eggs. The key question is how the sperm produces the increase in InsP $_{3}$ levels.

\section{Signalling by a sperm factor}

There have been many different ideas for how sperm may cause $\mathrm{InsP}_{3}$ production and $\mathrm{Ca}^{2+}$ release in eggs. These are covered in many previous reviews (Stricker 1999, Kurakawa et al., 2004; Runft et al., 2002; Swann et al., 2006; Whitaker, 2007). A consensus of opinion has emerged that $\mathrm{Ca}^{2+}$ signalling in mammalian fertilization is initiated by the introduction of a sperm factor into the egg after sperm-egg membrane fusion. This fusion event occurs a few minutes before the first $\mathrm{Ca}^{2+}$ release in the mouse egg and this means there is ample time for a factor to 
diffuse into the egg (Lawrence et al., 1997; Jones et al., 1998a). The initial direct evidence for the existence of such a soluble sperm factor came from the observation that injecting soluble sperm extracts could trigger $\mathrm{Ca}^{2+}$ oscillations similar to those seen at fertilization in hamster and mouse eggs (Swann, 1990). Such a sperm factor has now been shown in other species such as pigs and humans (Kurakawa et al., 2004; Swann et al., 2006). Important clues to the nature of the sperm factor came from studies using the sea urchin egg homogenate. It was found that the mammalian sperm factor causes a large increase in Ins $\mathrm{P}_{3}$ and $\mathrm{Ca}^{2+}$ release from intracellular vesicles in this egg homogenate (Jones et al., 1998b). Similarly injection of the sperm factor into frog eggs has been shown to cause and increase in $\operatorname{lns}_{3}$ that can be measured by bioassay (Wu et al., 2001). Injecting the sperm protein factor into mouse eggs has also been shown to cause down regulation of $\mathrm{InsP}_{3}$ receptors which is a sign that an $\operatorname{InsP}_{3}$ increase has occurred (Lee et al., 2006). The work in sea urchin egg homogenates also showed that the sperm extract themselves possessed a high PLC activity (Jones et al., 1998b; Rice et al., 2000). This suggested that the sperm factor was itself a phosphoinositide (PI) specific PLC. The problem with this hypothesis was that injecting the known isoforms of PI specific PLC did not cause $\mathrm{Ca}^{2+}$ oscillations in eggs (Jones et al., 2000), or else where they were reported to cause $\mathrm{Ca}^{2+}$ oscillations, such as with PLC $\gamma$, the concentrations of PLC were hundreds of times greater than the PLC activity found in a single sperm (Mehlmann et al., 2001). The resolution to this conundrum came with discovery of a novel, sperm specific, PLC isoform.

\section{PLC $\zeta$ and $\mathrm{Ca}^{2+}$ release at fertilization}

PLC zeta (PLC $\zeta$ ) was first identified as a novel form of PLC expressed exclusively in testis (Saunders et al., 2002). It has a molecular mass of $\sim 70 \mathrm{kDa}$ which makes it the smallest of the mammalian PI specific PLCs (Rebecchi and Pentyala 2000). It is closest in primary sequence to the $\delta$ class of PLCs. PLC $\zeta$ consist of four EF hand domains that bind $\mathrm{Ca}^{2+}$, a $\mathrm{C} 2$ domain, and $\mathrm{X}$ and $Y$ catalytic domains found in all mammalian PLCs. It is notably different from most other mammalian phosphoinositide specific PLCs in lacking a $\mathrm{PH}$ domain. When the cRNA for PLC $\zeta$ or recombinant $P L C \zeta$ protein is injected into mouse eggs it triggers $\mathrm{Ca}^{2+}$ oscillations very similar to those seen at fertilization (Saunders et al., 2002; Kouchi et al., 2004). Fig. 1B shows an example of a mouse egg undergoing $\mathrm{Ca}^{2+}$ oscillations after injection of PLC $\zeta$ cRNA. Immunodepletion of PLC $\zeta$ from sperm extracts abolishes their ability to cause $\mathrm{Ca}^{2+}$ oscillations in mouse eggs. This suggests that the previously described sperm factor is PLC $\zeta$ (Swann et al., 2006; Saunders et al., 2007).

There is every indication that PLC $\zeta$ is involved in causing $\mathrm{Ca}^{2+}$ oscillations in fertilizing mammalian eggs. A PLC $\zeta$ isoform has now been identified in at eight mammalian species and in many cases it has been shown to trigger $\mathrm{Ca}^{2+}$ oscillations in eggs (Swann et al., 2006). The amount of PLC $\zeta$ that is required to trigger $\mathrm{Ca}^{2+}$ oscillations is within the range of $\mathrm{PLC} \zeta$ in a single sperm (Saunders et al., 2002). The release of PLC $\zeta$ from sperm probably occurs well within the first hour after sperm-egg fusion and this correlates with the time over which the $\mathrm{Ca}^{2+}$ oscillations occur (Yoon and Fissore, 2007). There also now evidence that $\mathrm{PLC} \zeta$ is the factor responsible for causing $\mathrm{Ca}^{2+}$ oscillation after intracytoplasmic sperm injection (Fujimoto et al., 2004).

Only one study to date has directly addressed the requirement of PLC $\zeta$ in normal fertilization. The knockdown of PLC $\zeta$ in sperm using a transgenic RNAi approach has been shown to reduce the number of $\mathrm{Ca}^{2+}$ oscillations and reduce the activation rates at fertilization (Knott et al., 2005). This transgenic approach generates mosaic expression in spermatogenic cells, and some sperm would still contain some PLC $\zeta$ that could account for why some sperm can still cause some $\mathrm{Ca}^{2+}$ oscillations and egg activation. One noteworthy feature, however, is that the transgene was never passed on from males to the next generation. This implies that sperm carrying the transgene, where PLC $\zeta$ would be most reduced, are not able to trigger an egg to activate and develop. This implies that PLC $\zeta$ is required for normal fertility in male mice (Knott et al., 2005). The actions of PLC $\zeta$ appears to be specific to egg since transgenic expression of PLC $\zeta$ in somatic cells appears to have little effect. In the ovary PLC $\zeta$ expression it leads to spontaneous egg activation and the subsequent development of ovarian teratocarcinomas (Yoshida et al., 2007).

The mechanism of action and localization of PLC $\zeta$ in eggs is unclear. Studies using a Venus-tagged (hence highly fluorescent) version of PLC $\zeta$ have suggested that it is not specifically localized in the plasma membrane (Yoda et al., 2004). The apparent lack of specific plasma membrane localization could be due to the fact that PLC $\zeta$ lacks a PH domain which localizes the closely related PLC $\delta 1$ to the $\mathrm{PIP}_{2}$ in plasma membrane (Saunders et al., 2002). The parts of PLC $\zeta$ that may be involved in localization to a source of $\mathrm{PIP}_{2}$ are the $\mathrm{C} 2$ domain and a region between the $\mathrm{X}$ and $\mathrm{Y}$ catalytic domains called the X-Y linker (Kouchi et val. 2005; Nomikos et al., 2005). The $X-Y$ linker region has several basic residues that could help anchor it to $\mathrm{PIP}_{2}$ which is a very negatively charged phospholipid (Nomikos et al., 2007). However, it is still unclear whether the $\mathrm{PIP}_{2}$ that PLC $\zeta$ binds to is in the plasma membrane or an internal organelle. The only statement we can make about its localization is that PLC $\zeta$ enters the pronuclei as they form after mouse egg activation (Larman et al., 2004; Yoda et al., 2004;Yoon and Fissore, 2007). This localization appears to involve a nuclear targeting region in the $X-Y$ linker region of the protein that is the same as that proposed to bind to $\mathrm{PIP}_{2}$. The localization of PLC $\zeta$ in pronuclei is associated with the termination of $\mathrm{Ca}^{2+}$ oscillations and may act in conjunction with modifications to the Ins $\mathrm{P}_{3}$ receptor to terminate $\mathrm{Ca}^{2+}$ signals at fertilization (Larman et al., 2004; Lee et al., 2006). More extensive reviews of PLC $\zeta$ can be found elsewhere (Swann et al., 2006; Saunders et al., 2007).

\section{How does $\mathrm{Ca}^{2+}$ oscillate in an egg?}

The discovery of PLC $\zeta$ provides a foundation for understanding how $\mathrm{Ca}^{2+}$ oscillations are generated at fertilization. One of the features that distinguishes PLC $\zeta$ from other mammalian PLCs is the extraordinary sensitivity to $\mathrm{Ca}^{2+}$ ions due to the presence of $\mathrm{EF}$ domains that bind $\mathrm{Ca}^{2+}$ (Kouchi et al., 2005; Nomikos et al., 2005). The high sensitivity to $\mathrm{Ca}^{2+}$ was observed previously for the sperm factor associated PLC activity (Rice et al., 2000). Most, if not all, phosphoinositide specific PLCs show some stimulation by $\mathrm{Ca}^{2+}$ ions, but the level of $\mathrm{Ca}^{2+}$ required to stimulate the isolated enzyme is in the micromolar range which is well above the resting levels in cells (Rebecchi and Pentyala 2000). In contrast recom- 
binant $\mathrm{PLC} \zeta$ is stimulated by $\mathrm{Ca}^{2+}$ in the $100 \mathrm{nM}-800 \mathrm{nM}$ range in vitro. This means that once $\mathrm{PLC} \zeta$ is in the egg it is expected to generate Ins $\mathrm{P}_{3}$ at resting $\mathrm{Ca}^{2+}$ concentrations in eggs ( 100nM). Furthermore, when $\mathrm{Ca}^{2+}$ levels start to increase there will be a further increase in $\operatorname{InsP}_{3}$ production that will enhance the size of the $\mathrm{Ca}^{2+}$ increase. It is possible that egg-derived PLCs, such as $\mathrm{PLC} \beta$, could also contribute to $\operatorname{Ins}_{3}$ generation during the peak of such $\mathrm{Ca}^{2+}$ rises (Igirashi et al., 2007). This all implies a positive feedback of increased $\mathrm{Ca}^{2+}$ and $\mathrm{Ins}_{3}$ during the rising phase of each $\mathrm{Ca}^{2+}$ increase. Such positive feedback plays a central role in models of $\mathrm{Ca}^{2+}$ oscillations in some somatic cells (Meyer and Stryer, 1988; Harootunian et al., 1991; Hirose et al., 1999; Politi et al., 2006). The only explicit mathematical model of $\mathrm{Ca}^{2+}$ signals in eggs at fertilization to date is in ascidians where the best way of explaining repetitive $\mathrm{Ca}^{2+}$ waves is to assume that a highly $\mathrm{Ca}^{2+}$ sensitive $\mathrm{PLC}$ generated Ins $\mathrm{P}_{3}$ induced $\mathrm{Ca}^{2+}$ release (Dupont and Dumollard, 2004). Such an idea of $\mathrm{Ca}^{2+}$ dependent InsP $\mathrm{P}_{3}$ production in eggs dates back to one proposed to account to the singular $\mathrm{Ca}^{2+}$ wave at fertilization in the sea urchin egg (Whitaker and Irvine, 1983). It is possible that this idea could also account for waves and oscillations in mammalian eggs.

Although regenerative Ins $\mathrm{P}_{3}$ production is a plausible mechanism in eggs exact mechanism of $\mathrm{Ca}^{2+}$ oscillations has remained

\section{A InsP $_{3}$ receptor based oscillations}

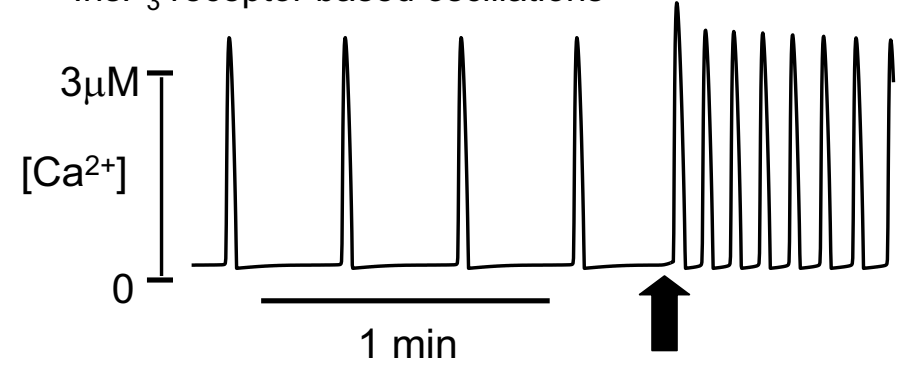

B $\mathrm{Ca}^{2+}$ activated PLC based oscillations

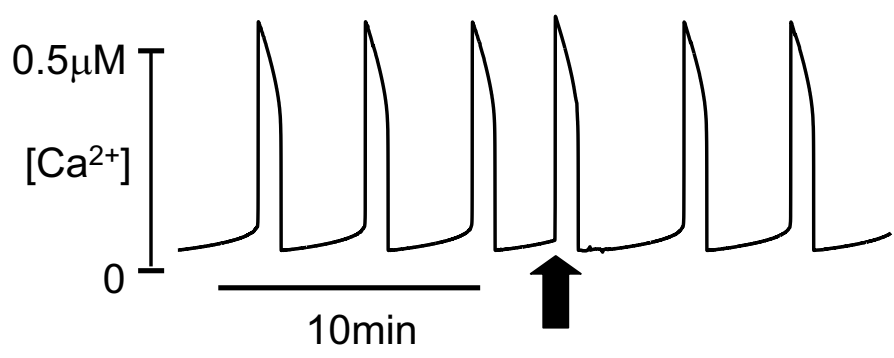

Fig. 2. Different models of $\mathrm{Ca}^{2+}$ oscillations respond differently to pulses of $\operatorname{Ins}_{\mathbf{3}}$. In (A), a simulation is shown for a model in which positive and negative feedback on the $\operatorname{Ins}_{3}$ receptor generate the oscillations. A sudden increase in Ins $P_{3}$ (indicated by the arrow) causes an increase in the frequency of oscillations. For the sake of illustration, in this case, InsP $P_{3}$ is slowly metabolized and so the increase lasts for some time, but a pulse of $I n s P_{3}$ in this model leads to an increase in the frequency of oscillations (Sneyd et al., 2006). In (B), a simulation is shown for oscillations generated by $\mathrm{Ca}^{2+}$ induced feedback on $\operatorname{Ins} \mathrm{P}_{3}$ production. A sudden increase in Ins $P_{3}$ leads to a $\mathrm{Ca}^{2+}$ transient that resets the oscillatio cycle, with no increase in frequency. The model and parameters are described in Sneyd et al. (2006). unresolved because there is another popular model of $\mathrm{Ca}^{2+}$ oscillations that involves positive and negative feedback loops of $\mathrm{Ca}^{2+}$ acting directly on the InsP $\mathrm{P}_{3}$ receptor (De Young and Keizer, 1992). In this model at low $\mathrm{Ca}^{2+}$ levels the $\operatorname{InsP}_{3}$ receptor is stimulated by $\mathrm{Ca}^{2+}$, but at higher $\mathrm{Ca}^{2+}$ levels the $\mathrm{InsP}_{3}$ receptor is closed by $\mathrm{Ca}^{2+}$ (Bezprozvanny etal., 1991). If this model is correct the $\operatorname{InsP}_{3}$ does not oscillate but instead it provides constant stimulation to the $\operatorname{lns}_{3}$ receptor that undergoes oscillatory openings. This idea has also received experimental verification in somatic cells. A fluorescent resonance energy transfer (FRET) indicator called IRIS-1, based upon the $\operatorname{InsP}_{3}$-binding domain of the InsP $_{3}$ receptor, has been used to show that $\operatorname{InsP}_{3}$ does not oscillate during metabotropic glutamate receptor stimulation of $\mathrm{Ca}^{2+}$ oscillations in HeLa cells (Matsu-ura et al., 2006). This model is supported in eggs by the finding that sustained injection of InsP $\mathrm{P}_{3}$ or its non hydrolysable derivative, or adenosphostin, or generating a sustained small Ins $\mathrm{P}_{3}$ increase by photorelease, can all lead to a series of $\mathrm{Ca}^{2+}$ oscillations in unfertilized hamster or mouse eggs (Swann et al., 1989; Swann, 1994; Galione et al., 1994; Nixon and Jones, 2000; Jellerette et al., 2000). This suggests that the $\operatorname{Ins}_{3}$ receptor alone can generate oscillations and that Ins $_{3}$ levels do not need to oscillate.

One way to try and resolve the mechanism of $\mathrm{Ca}^{2+}$ oscillations is to measure InsP $\mathrm{P}_{3}$ during fertilization. As, noted above, the GFP$\mathrm{PH}$ indicator used in many somatic cells is not useful for measuring Ins $\mathrm{P}_{3}$ in mammalian eggs. However, a different FRET based fluorescent indicator called fretino has been used to study the dynamics of Ins $\mathrm{P}_{3}$ in mouse eggs (Shirakawa et al., 2006). Like IRIS, this indicator is based upon Ins $\mathrm{P}_{3}$ binding to the bindingdomain of the InsP $_{3}$ receptor which contains two attached fluorescent proteins (Shirakawa et al., 2006). At fertilization this probe suggested there is an increase $\operatorname{lnsP}_{3}$, but the signal change is very small and not obviously oscillatory. However, after PLC $\zeta$ cRNA injection the $\mathrm{Ca}^{2+}$ oscillations eventually become associated with distinct oscillations in $\operatorname{InsP}_{3}$ (Shirakawa et al., 2006). One interpretation of these data is that the indicator is not sensitive enough to measure $\operatorname{lns}_{3}$ oscillations at fertilization but when PLC $\zeta$ is introduced into the egg via RNA injection there is a gradual increase in PLC $\zeta$ levels to that somewhat above physiological. This high level of PLC $\zeta$ is then sufficient to generate enough InsP $\mathrm{P}_{3}$ to be measurable as oscillations. However, it is also possible to argue that physiological levels of PLC $\zeta$ at fertilization are insufficient to lead to the $\operatorname{InsP}_{3}$ oscillations, or that $\operatorname{lns} \mathrm{P}_{3}$ oscillations are an epiphenomena and not central to the oscillatory mechanism.

\section{Distinguishing between different models of $\mathrm{Ca}^{2+}$ oscil- lations}

It is difficult to distinguish between the two different models for $\mathrm{Ca}^{2+}$ oscillations. Either one can apply depending upon the cell type and stimulus. One method proposed to distinguish between mechanisms is based upon introducing a sudden increase in Ins $\mathrm{P}_{3}$ using, for example, photo-release of a caged InsP $\mathrm{P}_{3}$ (Sneyd et al., 2006). The effect of a sudden pulse of $\operatorname{InsP}_{3}$ has very different effects depending upon the model of $\mathrm{Ca}^{2+}$ oscillations. If the model has InsP $\mathrm{P}_{3}$ as a control parameter (Ins $\mathrm{P}_{3}$ receptor based oscillations) then any transient increase in $\mathrm{InSP}_{3}$ leads to an increase in the frequency of $\mathrm{Ca}^{2+}$ oscillations. If, however, InsP 

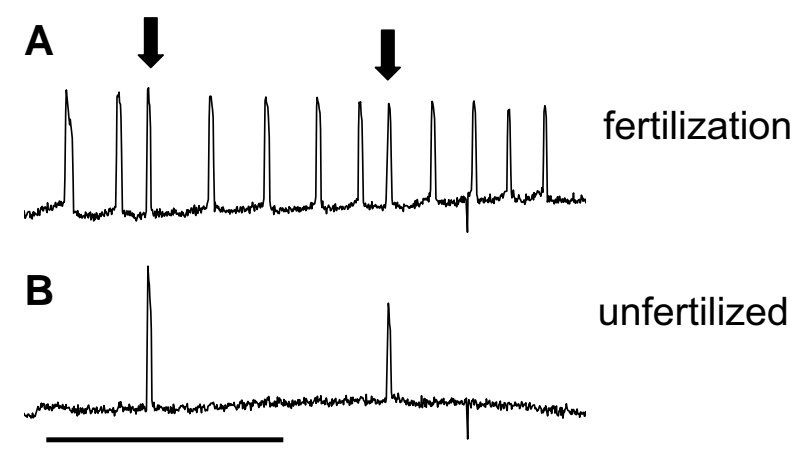

unfertilized egg

40 mins

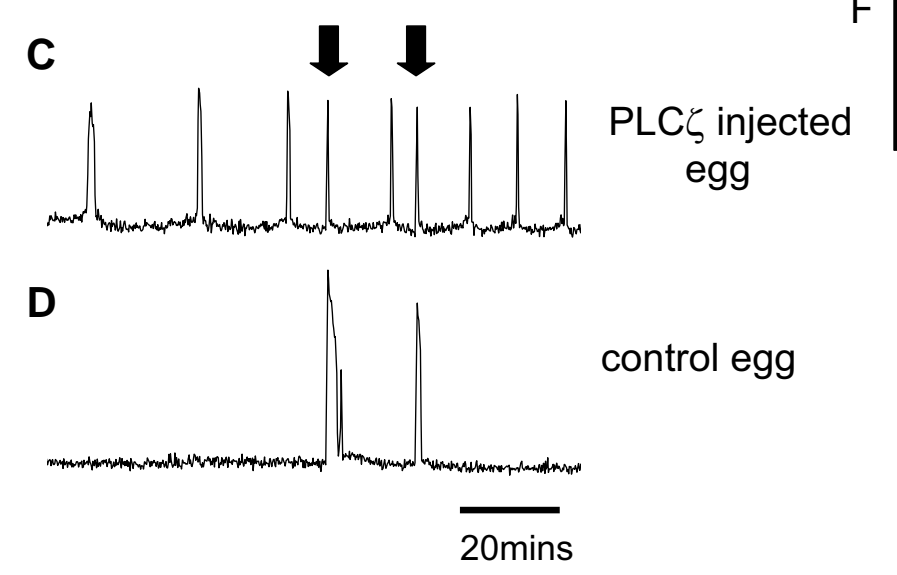

Fig. 3. Photorelease of caged Ins $\mathbf{P}_{\mathbf{3}}$ in mouse eggs. All eggs were injected with caged Ins $P_{3}(0.5 \mathrm{mM}$ in pipette) and Oregon green BAPTA dextran and conditions are as in Fig. 1. In (A), a fertilizing egg was exposed to (5s) pulses of UV light from a mercury lamp (with a UG11 filter) at the times indicated by the arrows. In (B), an egg that was in the same dish but that had not fertilized was exposed to the same UV pulses at the same time. In (C), an egg injected with PLC C CRNA was exposed to a (10s) UV pulse during oscillations, and (D) shows an uninjected egg in the same dish that also responded to the UV pulses. In all cases a large $\mathrm{Ca}^{2+}$ rise followed the photo-release of Ins $P_{3}$. In eggs undergoing oscillations, there was no obvious increase in the frequency of $\mathrm{Ca}^{2+}$ oscillations either at fertilization (example from 5 eggs), or after PLC $\zeta$ injection (example from 12 eggs).

is a dynamic component of the oscillation mechanism (regenerative Ins $\mathrm{P}_{3}$ production) then a sudden pulse increase in InsP $\mathrm{P}_{3}$ will cause a $\mathrm{Ca}^{2+}$ transient that resets the oscillation cycle and does not increase the frequency $\mathrm{Ca}^{2+}$ transients. This difference in response to perturbation is entirely robust with respect to other details of the mathematical model and it has been confirmed with 13 different models of $\mathrm{Ca}^{2+}$ oscillations (Sneyd et al., 2006). It provides a simple and qualitative way of discriminating which model of oscillations is operative in a cell.

In Fig. 2 some example simulations are shown for the two different types of mathematical model of $\mathrm{Ca}^{2+}$ oscillations (for details see Sneyd et al., 2006). In the case where oscillations occur via InsP $\mathrm{P}_{3}$ receptor feedback the sudden increase in Ins $\mathrm{P}_{3}$ leads to a marked increase in frequency of $\mathrm{Ca}^{2+}$ oscillations (Fig. $2 \mathrm{~A})$. In the case where Ins $\mathrm{P}_{3}$ undergoes regenerative increases, the sudden increase in Ins $\mathrm{P}_{3}$ causes a large $\mathrm{Ca}^{2+}$ increase but this does no lead to extra oscillations, but instead resets the oscillation cycle (Fig. 2B). Fig. 3 shows examples of experiments where $\mathrm{Ins}_{3}$ was increased suddenly in a fertilizing, or PLC $\zeta$ injected, mouse eggs by photo-release of caged InsP $\mathrm{P}_{3}$. In each case there is a sudden rise of $\mathrm{Ca}^{2+}$ that is similar to that seen in control unfertilized eggs. However, this does not lead to any sign of extra $\mathrm{Ca}^{2+}$ oscillations. Instead it resets the period of $\mathrm{Ca}^{2+}$ oscillations and the next transient occurs with a delay similar to the period prior to the pulse of $\operatorname{InsP}_{3}$. These results are consistent with the model of oscillations in which $\mathrm{Ca}^{2+}$ induced $\operatorname{InsP}_{3}$ production is involved in each $\mathrm{Ca}^{2+}$ rise (Hirose et al., 2002).

To reconcile the data in Fig. 3 with previous data on InsP $\mathrm{P}_{3}$ induced $\mathrm{Ca}^{2+}$ oscillations, we suggest that two mechanisms of $\mathrm{Ca}^{2+}$ oscillations exist in mammalian eggs in a manner illustrated in Fig. 4. In an unfertilized mammalian egg the $\operatorname{InsP}_{3}$ receptor alone provides the mechanism for generating $\mathrm{Ca}^{2+}$ oscillations that are seen, for example, in response to sustained InsP increases (Swann et al., 1989; Swann 1994; Nixon and Jones, 2000). This mechanism could also explain the spontaneous $\mathrm{Ca}^{2+}$ oscillations that are seen in immature mouse oocytes shortly after isolation from the ovary (Carroll and Swann, 1992; Nixon and Jones, 2000). After fertilization the sperm will have introduced PLC $\zeta$ and as a result oscillations are generated by a different mechanism involving a regenerative rise in $\operatorname{lns}_{3}$ during each $\mathrm{Ca}^{2+}$ transient. The regenerative and $\mathrm{Ca}^{2+}$ dependent InsP production in Fig. 4B also offers an explanation for the enhanced sensitivity of the eggs to ' $\mathrm{Ca}^{2+}$ induced $\mathrm{Ca}^{2+}$ release' (Igusa and Miyazaki, 1983). The so called ' $\mathrm{Ca}^{2+}$ induced $\mathrm{Ca}^{2+}$ release' could actually be $\mathrm{Ca}^{2+}$ induced InsP ${ }_{3}$ production which is only seen after fertilization because of the presence of PLC $\zeta$ (Shirakawa et al., 2006)

In support of the mechanisms proposed in Fig. 4 it is noteworthy that models involving just the kinetics of the $\operatorname{InsP}_{3}$ receptor tend to produce high frequency short duration oscillations with the time periods of less than a minute (Politi et al., 2006). This is why the mathematical model of $\mathrm{Ca}^{2+}$ oscillations based upon the $\mathrm{InsP}_{3}$ receptor in Fig. 2 are rather high frequency. This relatively high frequency response is similar to what is observed in immature oocytes, and in unfertilized hamster and mouse eggs injected with agents that stimulate the $\operatorname{InsP}_{3}$ receptor (Carroll and Swann, 1992; Swann et al., 1989; Galione et al., 1994; Swann, 1994; Jones and Nixon, 2000; Jellerette et al., 2000). In contrast models involving positive feedback of $\mathrm{Ca}^{2+}$ on $\mathrm{InsP}_{3}$ production can produce a much greater range of $\mathrm{Ca}^{2+}$ oscillations including those with time periods of many minutes as seen with fertilizing eggs (Politi et al., 2006). There could also be $\mathrm{Ca}^{2+}$ dependent metabolism of InsP $\mathrm{P}_{3}$ which would mean that InsP $\mathrm{P}_{3}$ oscillations would be even more strongly coupled to $\mathrm{Ca}^{2+}$ oscillations (Politi et al., 2006).

Although most of the debate over different ideas for oscillations revolves around the rising phase of each $\mathrm{Ca}^{2+}$ transient, there are various $\mathrm{Ca}^{2+}$ pumps such as the SERCA pumps that play an important role in returning $\mathrm{Ca}^{2+}$ to the $\mathrm{Ca}^{2+}$ stores (Kline and Kline, $1992 b)$. There is also some $\mathrm{Ca}^{2+}$ flux out of the cell due to a plasma membrane $\mathrm{Ca}^{2+}$ ATPase, and a Na+$/ \mathrm{Ca}^{2+}$ exchanger (Georgou et al., 1998; Carroll 2000). In compensation for the efflux, a small influx of $\mathrm{Ca}^{2+}$ into the egg appears to occur during each $\mathrm{Ca}^{2+}$ transient (McGuinness et al., 1996). $\mathrm{Ca}^{2+}$ uptake into mitochondria occurs (Dumollard et al., 2007), and it is possible that a cycle of $\mathrm{Ca}^{2+}$ through other compartment, such as the mitochondria, 
could play a role in setting up the frequency of $\mathrm{Ca}^{2+}$ oscillations (Ishii et al., 2006). However, the $\mathrm{Ca}^{2+}$ dynamics inside the various compartments in eggs has not yet been reported.

\section{How might an egg decode $\mathrm{Ca}^{2+}$ oscillations?}

The multiple increases in $\mathrm{Ca}^{2+}$ trigger all the major events at fertilization. Furthermore, with each $\mathrm{Ca}^{2+}$ increase there is a progressive stimulation of each process (Ducibella et al., 2006). This is shown most directly by using repetitive electroporation to drive different numbers of $\mathrm{Ca}^{2+}$ increases in eggs and induce parthenogenetic activation (Ozil and Hunaeu 2001). Some events such as meiotic resumption are stimulated early by a single $\mathrm{Ca}^{2+}$ transient, whilst other events such as the decreases in activity of cell cycle protein kinases requires more $\mathrm{Ca}^{2+}$ transients (Ducibella et al., 2002). Exocytosis occurs in a stepwise manner with each pulse of $\mathrm{Ca}^{2+}$ stimulating a loss of cortical granules from the egg (Ducibella et al., 2002). This suggests that, during normal fertilization, mammalian eggs respond in an integral way to pulses of $\mathrm{Ca}^{2+}$ release. In turn this implies that some downstream components in the egg may read out the number, or frequency, of $\mathrm{Ca}^{2+}$ increases in eggs (Dupont and Goldbeter, 1998). It is of particular interest, therefore, to examine enzymes or signalling modules that can be seen to be 'decoding' the oscillatory signal.

One of the immediate targets of the $\mathrm{Ca}^{2+}$ increases in eggs is the cell cycle machinery that keeps the egg arrested in metaphase of the second meiosis. The resumption of meiosis is stimulated through a series of changes in the activity of protein kinases (Carroll, 2001; Jones 2007). This results in the stimulation of the anaphase promoting complex/cyclosome which leads to proteolysis of cyclin $B$ that is required to maintain the CDK1 (cell division cycle kinase) activity responsible for arrest in meiosis II (Carroll 2001; Jones 2007). The dynamics of cyclin B destruction has been measured at fertilization using GFP-tagged cyclin B and it has been shown that cyclin $B$ is rapidly destroyed at the onset of $\mathrm{Ca}^{2+}$ oscillations (Nixon et al., 2002). The early studies suggested that each $\mathrm{Ca}^{2+}$ spike might lead to a distinct increment in cyclin B destruction (Nixon et al., 2002). However, subsequent studies suggest a non oscillatory, steady decline in cyclin B following the onset of $\mathrm{Ca}^{2+}$ oscillations (Marangos and Carroll, 2004). The kinetics of CDK1 activity during fertilization have yet to be determined with the time resolution applied to cyclin B.

Most recent attention has focussed on calmodulin dependent protein kinase II, or CaMKII, as a transducer of the $\mathrm{Ca}^{2+}$ signal at fertilization. CaMKII activity is stimulated at fertilization (Markoulaki et al., 2004), and this is significant because it can phosphorylate Emi2 which targets it for destruction and sets in train the activation of the anaphase promoting complex (Jones 2007). The destruction of Emi2 has also been measured with a fluorescent protein tag and its destruction during $\mathrm{Sr}^{2+}$ induced egg activation precedes cyclin B destruction, but it is not clear if the destruction is oscillatory (Madgwick et al., 2006). The full effects of CaMKII in eggs have been directly assessed by injection a constitutively activate form of CaMKII (CA-CaMKII). The injection of cRNA for CA-CaMKII into mouse eggs leads to meiotic resumption and initiation of the first cell cycles and development up to the blastocyst stage (Madgwick etal., 2005; Knott et al., 2006). These data suggest that CaMKII is the major transducer of the $\mathrm{Ca}^{2+}$ oscillations in fertilizing mammalian eggs. This is of particular
A Injecting Ins $_{3}$ into an unfertilized egg
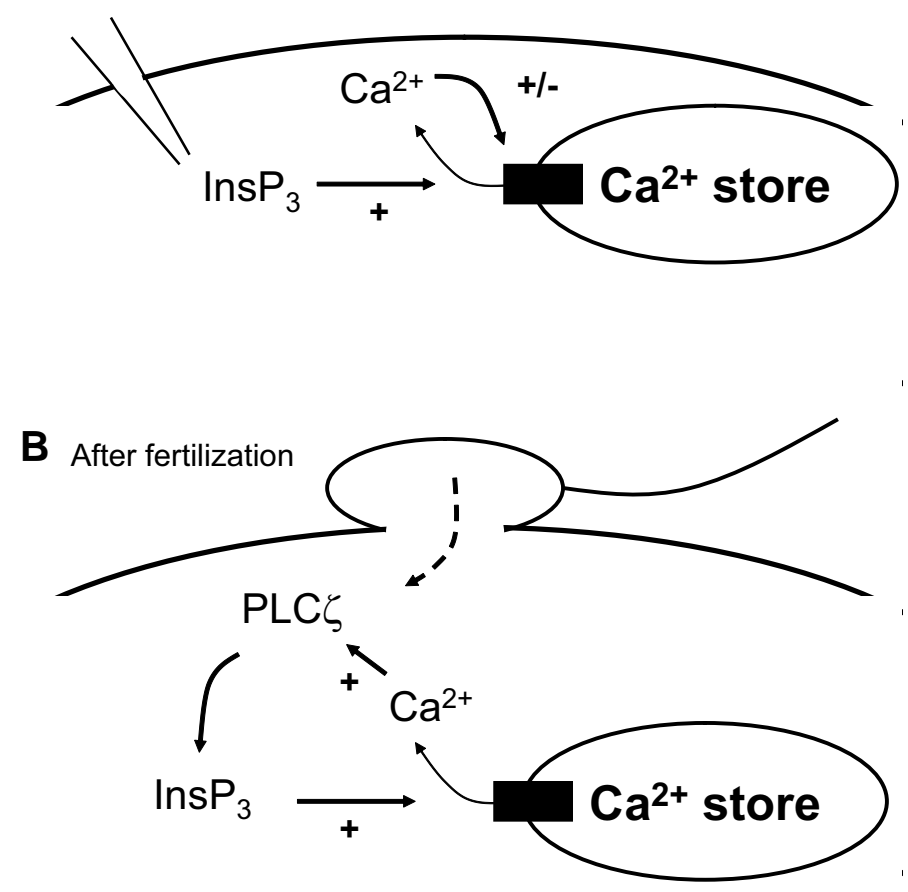

Fig. 4. A schematic diagram to illustrate the different oscillates that are proposed to exist in mammalian eggs. In both cases, $\mathrm{Ca}^{2+}$ release occurs from an intracellular store via the $\operatorname{lns} P_{3}$ receptors (the black rectangle). (A) When Ins $P_{3}$, or its derivatives, are microinjected into an unfertilized eggs the oscillations are proposed to be solely due to the feedback properties of the Ins $P_{3}$ receptor. (B) In contrast, after fertilization the introduction of PLC $\zeta$ introduced a new positive feedback loop which takes over as the mechanism of oscillations.

interest because CaMKII can undergo auto-activation and stay active after a decrease in cytosolic $\mathrm{Ca}^{2+}$ levels (De Konick and Schulman 1998). It can show a level of activity that is a 'read out' of the frequency of $\mathrm{Ca}^{2+}$ oscillations (De Konick and Schulman, 1998; Dupont and Goldbeter, 1998). However, the data that shows that CaMKII activity acts as such an analogue transducer of $\mathrm{Ca}^{2+}$ oscillations in neurons, for example, involves very high frequency $\mathrm{Ca}^{2+}$ pulses $(>1 \mathrm{~Hz})$ compared with those in mammalian eggs $(<0.005 \mathrm{~Hz}$ ) (De Konick and Schulman, 1998; Dupont and Goldbeter,1998). When the auto-activation of CaMKII is measured in mouse eggs, it undergoes an increase, and then a decrease in activity, essentially in phase with each $\mathrm{Ca}^{2+}$ transient (Markoulaki et al., 2004). In other words CaMKIl activity does not show any long term memory of each $\mathrm{Ca}^{2+}$ pulse. So CaMKII itself, in eggs, does not appear to act as the 'analogue output' of $\mathrm{Ca}^{2+}$ oscillations in the way suggested in neurons (De Konick and Schulman, 1998). If there is a decoder of $\mathrm{Ca}^{2+}$ oscillations in eggs it probably involves downstream protein substrates of CaMKII that could be reversibly phosphorylated (Dupont and Goldbeter, 1998; Ducibella et al., 2006).

As well as CaMKII, other protein kinases may be involved in turning the $\mathrm{Ca}^{2+}$ signals into cellular responses. For example a number of different protein kinase $\mathrm{C}$ isoforms are expressed in mammalian eggs, including both the conventional isoforms that can be activated by the $\mathrm{Ca}^{2+}$ and diacylglycerol (Halet 2004). 
PLC $\zeta$ is expected to produce DAG as well as InsP $P_{3}$, so this could act in concert to stimulate PKC. Indeed at fertilization there is an increase in PKC activity (Tatone et al., 2003), and different isoforms undergo translocation to either the plasma membrane or meiotic spindle (Tatone et al., 2003; Page Baluch et al., 2004). The stimulation of PKC could play a number of roles at fertilization since phorbol esters, which can mimic the effects of DAG stimulation in stimulating PKC, has been reported to cause egg activation and even trigger small $\mathrm{Ca}^{2+}$ oscillations (Cuthbertson and Cobbold, 1985; Colonna et al., 1989). However, the injection of a constitutively activated form of PKC $\alpha$ does not cause $\mathrm{Ca}^{2+}$ oscillations or meiotic resumption in mouse eggs so its role in activation is unclear (Madgwick et al., 2004). The role of PKC is made more complex to understand by the existence of non-conventional PKC isoforms that are not stimulated by $\mathrm{Ca}^{2+}$, and the finding that the increase in PKC activity in eggs is not much affected by inhibiting $\mathrm{Ca}^{2+}$ transients at fertilization (Tatone et al., 2003; Halet 2004). On the other hand PKC stimulation has the potential to alter $\mathrm{Ca}^{2+}$ oscillations at fertilization since either phorbol esters, or a constitutively activate PKC, can enhance $\mathrm{Ca}^{2+}$ influx into mouse eggs (Halet et al., 2004; Madgwick et al., 2005).

Of the different isoforms PKC $\gamma$ is of particular interest with respect to $\mathrm{Ca}^{2+}$ oscillations. Rather like CamKII it has been suggested to act a 'decoding machine' for the frequency of $\mathrm{Ca}^{2+}$ oscillations (Oancea and Meyer, 1998). The only studies that have addressed the dynamics of $\mathrm{Ca}^{2+}$ oscillations and PKC activation have used plasma membrane translocation of GFP linked to either the whole of PKC $\gamma$ or PKC $\alpha$, or GFP linked to the C2 or C1 domains of PKC $\gamma$ (Halet et al., 2004). In many cellular systems the translocation of PKC via its specific domains is linked to enzyme activation so translocation is a surrogate assay for PKC stimulation. These studies have shown that PKC translocation occurs with each $\mathrm{Ca}^{2+}$ spike, with most activation occurring during the first $\mathrm{Ca}^{2+}$ transient which tends to be larger than subsequent responses (Halet et al., 2004). There are some indications that PKC does undergo incremental translocation during the series of rapid ( 30s) $\mathrm{Ca}^{2+}$ oscillations that occur on top of the initial $\mathrm{Ca}^{2+}$ transient at fertilization (Halet et al., 2004). However, there is no incremental translocation in response to the low frequency $\mathrm{Ca}^{2+}$ oscillations that occur over several hours. As with CaMKII, the PKC activity appears to track the overall pattern of $\mathrm{Ca}^{2+}$ changes and there is no obvious 'decoding' of the frequency of $\mathrm{Ca}^{2+}$ oscillations at this level. Again it is assumed that some substrates of PKC could act to integrate the pulses in PKC activity.

A different kind of target for $\mathrm{Ca}^{2+}$ oscillations at fertilization are the mitochondria. Mammalian eggs typically contain $>100,000$ mitochondria and rely on oxidative phosphorylation for ATP production throughout fertilization and the early cleavage divisions (Dumollard et al., 2004). During the $\mathrm{Ca}^{2+}$ oscillations in fertilizing mouse eggs it has been shown that there are a series of oscillatory increases in reduction of FAD and NAD (Dumollard et al., 2004b). It appears that $\mathrm{Ca}^{2+}$ increases in the cytosol result in $\mathrm{Ca}^{2+}$ increases in the mitochondrial matrix and this leads to stimulation of mitochondrial dehydrogenases. The direct stimulation of the mitochondria reduction could also explain the finding that the sperm-induced $\mathrm{Ca}^{2+}$ oscillations lead to a distinct and transient increase in ATP levels as monitored by firefly luciferase luminescence (Campbell and Swann, 2006).

Mitochondria have also been proposed to act as device for decoding $\mathrm{Ca}^{2+}$ oscillations in cells where the output is measured in terms of reduction mitochondrial NAD (Hajnoczky et al., 1995). There are indication that mitochondria in eggs can act as a unit to decode $\mathrm{Ca}^{2+}$ oscillations into an analogue response. $\mathrm{Ca}^{2+}$ oscillations are probably causing $\mathrm{Ca}^{2+}$ pulses in the eggs mitochondria (Dumollard et al., 2007). The $\mathrm{Ca}^{2+}$ stimulated NADH/FADH reduction that follows is also oscillatory but there is clearly some degree of memory and integration in that each increase in FADH, for example, outlasts each $\mathrm{Ca}^{2+}$ transient (Dumollard et al., 2004b; Dumollard et al., 2006). By the time we look at the ATP in the cytosol we find that these $\mathrm{Ca}^{2+}$ dependent events have lost their oscillatory pattern and instead there is a steady increase in ATP that is maintained for the duration of oscillations (Campbell and Swann, 2006). This is a rare example where we can trace the dynamics of a form of digital to analogue conversion in the egg's biochemistry. Unfortunately it is not known if a $\mathrm{Ca}^{2+}$ stimulated ATP increase has a direct function. It may be more significant that the ATP is not allowed to fall during the increased energy demands associated with $\mathrm{Ca}^{2+}$ pumping during $\mathrm{Ca}^{2+}$ oscillations. A transient fall in ATP levels in mouse oocytes has been shown to cause a decrease in the rate developmental to the expanded blastocyst stage after fertilization (Van Blerkom et al., 1995).

\section{Why does $\mathrm{Ca}^{2+}$ oscillate in an egg?}

One question that often arises with regards to the $\mathrm{Ca}^{2+}$ signals in mammalian eggs is why there are oscillations at all. It has been known for some time that $\mathrm{Ca}^{2+}$ ionophore, or ethanol can activate mammalian eggs by causing a single large rise in $\mathrm{Ca}^{2+}$ (Colonna et al., 1989; Ozil and Swann, 1995). Furthermore, so much of the $\mathrm{Ca}^{2+}$ signal seems to be transduced via CaMKII and yet egg activation and development can be achieved with a CA-CaMKII, which is presumably constant in activity. So oscillations in CaMKII are not necessary for egg activation and the question remains as to why $\mathrm{Ca}^{2+}$ levels normally oscillate?

One possibility is that the oscillations are simply a consequence of the non linear feedback loop of $\mathrm{Ca}^{2+}$ activated InsP production that is intrinsic to PLC $\zeta$. This may well be the case, but it should be noted that many eggs such as those of sea urchins or frogs have many of the same signalling components and yet display a single $\mathrm{Ca}^{2+}$ increase at fertilization (Stricker 1999). The difference is not likely to be the absence or presence of PLC $\zeta$ in mammalian eggs because even injection of the sperm factor into a frog egg (Wu et al., 2001) causes only a single large $\mathrm{Ca}^{2+}$ increase. So the $\mathrm{Ca}^{2+}$ release machinery, or toolkit, can be put together in a way that does not lead to oscillations.

One reason why a single $\mathrm{Ca}^{2+}$ increase of the type seen in frog or sea urchins eggs is not seen in mammalian fertilization probably has to do with efficiency. A single $\mathrm{Ca}^{2+}$ increase generated by $\mathrm{Ca}^{2+}$ ionophore, or by electroporation to keep $\mathrm{Ca}^{2+}$ high for 510 minutes is generally not very efficient at activating eggs. Agents that cause such a single $\mathrm{Ca}^{2+}$ increase work best with mammalian eggs that are aged in vivo. When eggs are treated with a single large $\mathrm{Ca}^{2+}$ increase the activation rate of freshly ovulated mouse eggs is very low (Ozil and Swann, 1995; Toth et al., 2006). A much better protocol for activation is to expose eggs to a single large $\mathrm{Ca}^{2+}$ increase and then follow this with a series 
of extra smaller pulse of $\mathrm{Ca}^{2+}$, that in effect resemble the pattern seen at fertilization (Toth et al., 2006). A single 5-10 minute $\mathrm{Ca}^{2+}$ increase is often a poor stimulus for activation because, despite cyclin $\mathrm{B}$ degradation and polar body emission after one $\mathrm{Ca}^{2+}$ transient, the continued synthesis of cyclin $\mathrm{B}$ can lead to a return of cyclinB/CDK1 activity and the re-establishment of meiotic arrest in some eggs (Ducibella et al., 2002). This is why the most general protocol for egg activation uses a $\mathrm{Ca}^{2+}$ ionophore plus either a protein synthesis inhibitor, or a protein kinase inhibitor, which block either the re-synthesis of cyclin B or activity of CDK1.

Whilst it is clear that a relatively short singular $\mathrm{Ca}^{2+}$ stimulus (510 mins) is not always effective in activating eggs, a more difficult question is raised when a longer duration, but sustained, $\mathrm{Ca}^{2+}$ rise is applied to eggs. For example, electroporation can be used to cause prolonged elevations of $\mathrm{Ca}^{2+}$ in the egg and if the period of a $\mathrm{Ca}^{2+}$ increase is extended to more than 20 minutes, the egg activation can be effectively triggered (Ozil et al., 2005). In fact it has been suggested that it is the total sum of elevated $\mathrm{Ca}^{2+}$ this is important in stimulating egg activation rather than any particular pattern of $\mathrm{Ca}^{2+}$ pulses (Ozil et al., 2005; Toth et al., 2006). This suggests that stimulating an egg to go through the first cell cycle is less dependent upon the form of $\mathrm{Ca}^{2+}$ increase so long as enough $\mathrm{Ca}^{2+}$ is released.

The answer to this second issue may be more subtle and connected with later events in development. The eggs that are activated by a single $\mathrm{Ca}^{2+}$ increase do not develop as well after implantation as ones activated by multiple $\mathrm{Ca}^{2+}$ pulses (Ozil et al., 2005). This is consistent with studies that have shown that the pattern of $\mathrm{Ca}^{2+}$ oscillations during activation influences the size and morphology of post-implantation parthenogenetic rabbit embryos, or fertilized mouse embryos (Ozil and Huneau, 2001; Ozil et al., 2006). In a similar vein the protocol of exposing mouse eggs to different duration $\mathrm{Sr}^{2+}$ treatments, to induced different durations of $\mathrm{Ca}^{2+}$ oscillations, has been shown to effect the cell composition of blastocysts (Bos-Mikich et al., 1997). These data all imply that there might be some range of patterns of $\mathrm{Ca}^{2+}$ oscillations that is best for embryo development in mammals and that this is not connected with the immediate task of getting the embryo through the first cell cycle. This idea is supported by the development of eggs that are activated without any $\mathrm{Ca}^{2+}$ increase at all. Inhibitors of protein synthesis such as cycloheximide, or inhibitors of CDK1, such as roscovtine, can activate mouse eggs and stimulate them to proceed through the first couple of cell cycles without causing any $\mathrm{Ca}^{2+}$ increase (Rogers et al., 2006). However, embryo development to the blastocyst stage is very poor compared to embryos activated by $\mathrm{Sr}^{2+}$ that causes $\mathrm{Ca}^{2+}$ oscillations (Rogers et al., 2006). It is far from clear how the presence or absence of different patterns of $\mathrm{Ca}^{2+}$ oscillations can influence later development in mouse. It has been shown that either the absence or presence of different patterns of $\mathrm{Ca}^{2+}$ oscillations can influence the pattern of gene expression in mouse embryos (Rogers etal., 2006; Ozil etal., 2006). This serves to repose the question in terms of how $\mathrm{Ca}^{2+}$ changes during activation can influence later gene expression. Further progress on this and related questions will require that more of the downstream effects of $\mathrm{Ca}^{2+}$ are monitored with the same temporal resolution that we can apply to $\mathrm{Ca}^{2+}$ itself.

\section{Acknowledgements}

We thank Tony Lai, John Carroll, Guillaume Halet and Keith Jones for comments on the manuscript. Our work is supported by the BBSRC and the Wellcome Trust.

\section{References}

BEZPROZVANNY I, WATRAS J AND EHRLICH BE (1991) Bell-shaped calciumresponse curves of Ins(1,4,5)P3- and calcium-gated channels from endoplasmic reticulum of cerebellum. Nature 351:751-754.

BRIND S, SWANN K, AND CARROLL J. (2000) Inositol 1,4,5-trisphosphate receptors are downregulated in mouse oocytes in response to sperm and adenophostin $\mathrm{A}$ but not to and increase in intracellular $\mathrm{Ca}^{2+}$ or egg activation. Dev. Biol. 223: 251-265

BOS-MIKICH A, WHITTINGHAM DG AND JONES KT (1997) Meiotic and mitotic $\mathrm{Ca}^{2+}$ oscillations affect cell composition in resulting blastocysts. Dev. Biol. 182: $172-179$

CARROLL $J(2000) \mathrm{Na}^{-}-\mathrm{Ca}^{2+}$ exchange in mouse oocytes: modifications in the regulation of intracellular free $\mathrm{Ca}^{2+}$ during oocyte maturation. J. Reprod. Fertil. 118: $337-342$

CARROLL J. (2001) The initiation and regulation of $\mathrm{Ca}^{2+}$ signalling at fertilization in mammals. Semin Cell Dev Biol. 12: 37-43

CARROLL J AND SWANN K (1992) Spontaneous cytosolic calcium oscillations driven by inositol trisphosphate occur during in vitro maturation of mouse oocytes J. Biol. Chem. 267: 11196-1201

CAMPBELL,K. \& SWANN,K. (2006) $\mathrm{Ca}^{2+}$ oscillations stimulate an ATP increase during fertilization of mouse eggs. Dev. Biol. 298: 225-233

COLONNA R, TATONE C, MALGAROLI A, EUSEBI F AND MANGIA F (1989) Effects of protein kinase $\mathrm{C}$ stimulation and free $\mathrm{Ca}^{2+}$ rise in mammalian egg activation. Gamete Res. 24: 171-183

CUTHBERTSON KS, WHITTINGHAM DG AND COBBOLD (1981) Free $\mathrm{Ca}^{2+}$ increases in exponential phases during mouse oocyte activation. Nature 294: 754-757

CUTHBERTSON KS AND COBBOLD PH (1985) Phorbol ester and sperm activate mouse oocytes by inducing sustained oscillations in cell $\mathrm{Ca}^{2+}$. Nature 316: 541 542

DEKONICK P AND SCHULMAN H (1998) Sensitivity of CaM kinase II to the frequency of $\mathrm{Ca}^{2+}$ oscillations. Science 279: 227-230

DEYOUNG GW AND KEIZER J (1992) A single pool inositol 1,4,5 trisphophate receptor based model for agonist stimulated oscillations in $\mathrm{Ca}^{2+}$ concentration. Proc Natl Acad Sci. 89: 9895-9899

DUCIBELLA T, HUNEAU DS, ANGELICHIO E, XU Z, SCHULTZ RM. KOPG GS, FISSORE RA, MADOUX S AND OZIL JP. (2002) Egg to embryo transition is driven by differential responses to $\mathrm{Ca}^{2+}$ oscillation number. Dev. Biol. 250: 280291

DUCIBELLA T, SCHULTZ RM AND OZIL JP (2006) Role of calcium signals in early development. Sem. Cell Dev. Biol. 17: 324-332

DUMOLLARD R, MCDOUGHALL A, ROUVIERE C AND SARDET C (2004a) Fertilisation calcium signals in the ascidian egg. Biol. Cell. 96: 29-36

DUMOLLARD, R., MARANGOS, P., FITZHARRIS, G., SWANN, K., DUCHEN, M. AND CARROLL, J. (2004b) Sperm-triggered $\left[\mathrm{Ca}^{2+}\right.$ ] oscillations and $\mathrm{Ca}^{2+}$ homeostasis in the mouse egg have an absolute requirement for mitochondrial ATP production. Development 131: 3057-3067

DUMOLLARD R, DUCHEN M AND CARROLL J (2007) The role of mitochondrial function in the oocyte and embryo. Curr. Top. Dev. Biol. 77: 21-49

DUPONT G AND GOLDBETER A (1998) CamKII as frequency decoder of $\mathrm{Ca}^{2+}$ oscillations. Bioessays 20: 607-610

DUPONT G AND DUMOLLARD R (2004) Simulation of calcium waves in ascidian eggs: insights into the origin of the pacemaker sites and the possible nature of the sperm factor. J. Cell Science 117: 4313-4323

FUJIMOTO S, YOSHIDA N, FUKUI T, AMANAI M, ISOBE T, ITAGAKI C, IZUMI T. PERRY A C F. (2004) Mammalian phospholipase Cz induces oocyte activation from the sperm perinuclear matrix. Dev. Biol. 274: 370-383

FULTON, BP AND WHITTINGHAM DG (1978) Activation of mammalian oocytes by intracellular injection of calcium. Nature 273: 149-151

GALIONE A, SWANN K, GEORGIOU P AND WHITAKER M. (1994) Regenerative 
and non-regenerative calcium transients in hamster eggs triggered by inositol 1,4,5-trisphosphate. J. Physiol. 480: 465-474

GEORGOU,P., HOUSE,C.R., MCNIVEN,A.I. AND YOSHIDA,S. (1988) On the mechanism of a $\mathrm{pH}$ induced rise in membrane potassium conductance in hamster eggs. J. Physiol. 402: 121-138

HAJNOCCZKY G, ROBB-GASPERS LD, SEITZ MB AND THOMAS AP (1995) Decoding of cytosolic $\mathrm{Ca}^{2+}$ oscillations in the mitochondria. Ce//82: 415-424

HALET G, TUNWELL R, BALLAT, SWANN K, AND CARROLL J. (2002) The dynamics of plasma membrane Ptdlns $(4,5) \mathrm{P}_{2}$ at fertilization of mouse eggs. $J$ Cel/ Sci. 115: 2139-2149

HALET, G., TUNWELL, R., PARKINSON, S. J. AND CARROLL, J. (2004) Conventional PKCs regulate the temporal pattern of $\mathrm{Ca}^{2+}$ oscillations at fertilisation in mouse eggs. J. Cell Biol. 164: 1033-1044

HALET,G. (2004) PKC signalling at fertilization in mammalian eggs. Biochem. Biophys. Acta. 1742: 185-189

HAROOTUNIAN AT, KAO JP, PARANJAPE S AND TSEIN RY (1991) Generation of calcium oscillations in fibroblasts by positive feedback between calcium and IP3. Science 251: 75-78

HIROSE K, KADOWAKI S, TANABE M, TAKESHIMA H AND IINO M (1999) Spatialtemporal dynamics of inositol 1,4,5 trisphosphate that underlies complex $\mathrm{Ca}^{2+}$ mobilization patterns. Science 284: 1527-1530

IGIRASHI H, KNOTT JG, SCHULTZ RM AND WILLIAMS CJ (2007) Alterations of PLCbeta1 in mouse eggs change calcium oscillatory behavior following fertilization. Dev. Biol. (Epub ahead of print)

IGUSA Y AND MIYAZAKI S (1981) Fertilization potential in golden hamster eggs consists of recurring hyperpolarizations. Nature 290: 702-704

IGUSA Y AND MIYAZAKI S (1982) Ca-mediated activation of a K current at fertilization of golden hamster eggs. Proc. Natl. Acad. Sci. 79: 931-935

IGUSA Y AND MIYAZAKI S (1983) Effects of altered extracellular and intracellular calcium concentration on hyperpolarizing responses of the hamster egg. J. Physiol. 340, 633-647

ISHII K, HIROSE K AND IINO M (2006) $\mathrm{Ca}^{2+}$ shuttling between endoplasmic reticulum and mitochondria underlying $\mathrm{Ca}^{2+}$ oscillations. EMBO Rep. 7: 390396

JELLERETTE,T., HE,C.L., WU,H., PARYS,J.B. AND FISSORE,R.A. (2000) Downregulation of the inositol 1,4,5-trisphosphate receptor in mouse eggs following fertilization or parthenogenetic activation. Dev. Biol. 223: 238-250

JONES KT, SOELLER C AND CANNELL MB (1998a) The passage of $\mathrm{Ca}^{2+}$ and fluorescent markers between the sperm and egg after fuision in the mouse. Development 125: 4627-4635

JONES KT, CRUTTWELL C, PARRINGTON J, AND SWANN K. (1998b). A mammalian sperm cytosolic phospholipase $C$ activity generates inositol trisphosphate and causes $\mathrm{Ca}^{2+}$ release in sea urchin egg homogenates. FEBS Lett 437:297-300

JONES,K.T., MATSUDA,M., PARRINGTON,J., KATAN,M. AND SWANN,K. (2000) Different $\mathrm{Ca}^{2+}$ releasing abilities of sperm extracts compared with tissue extracts and phospholipase $\mathrm{C}$ isoforms in sea urchin egg homogenate and mouse eggs. Biochemical Journa/346: 743-749.

JONES,K.T. (2007) Intracellular calcium in the fertilization development of mammalian eggs. Clin. Exper. Pharm. Physiol. 34: 1084-1089

JONES KT, SOELLER C AND CANNELL MB (1998) The passage of $\mathrm{Ca}^{2+}$ and fluorescent markers between the sperm and egg after fusion in the mouse. Development 125: 4627-4635

KLINE D, AND KLINE JT. (1992a) Repetitive calcium transients and the role of calcium in exocytosis and cell cycle activation in the mouse egg. Dev Biol. 149: 80-89.

KLINE D AND KINE JT (1992b) Thapsigargin activates a calcium influx pathway in the unfertilized mouse egg and suppresses repetitive calcium transients in the fertilized egg. J. Biol. Chem. 267: 17624-30.

KNOTT JG, KUROKAWA M, FISSORE RA, SCHULTZ RM, AND WILLIAMS CJ (2005) Transgenic RNAi reveals role for mouse sperm phospholipase $C \zeta$ in triggering $\mathrm{Ca}^{2+}$ oscillations during fertilization. Biol. Reprod. 72: 992-996

KNOTT,J.G., GARDNER,A.J., MADGWICK,S.,JONES,K.T., WILLIAMS,C.J. AND SCHULTZ,R. (2006) Calmodulin-dependent protein kinase II triggers mouse egg activation and embryo development in the absence of $\mathrm{Ca}^{2+}$ oscillations.
Dev. Biol. 296: 388-395

KOUCHI Z, FUKAMI K, SHIKANOT, ODA S, NAKAMURA Y, TAKENAWA T, AND MIYAZAKIS. (2004) Recombinant phospholipase Czeta has high $\mathrm{Ca}^{2+}$ sensitivity and induces $\mathrm{Ca}^{2+}$ oscillations in mouse eggs. J. Biol Chem. 279: 1040810412

KOUCHIZ, SHIKANOT, NAKAMURAY, SHIRAKAWA, H, FUKAMIK, AND MIYAZAKI S. (2005) The role of EF-hand domains and C2 domain in regulation of enzymatic activity of phospholipase Czeta. J. Biol Chem. 280: 21015-21021

KURAKAWA M, SATO, K AND FISSORE RA (2004) Mammalian fertilization: from sperm factor to PLCzeta. Biol. Cel/96: 37-45

LARMAN MG, SAUNDERS CM, CARROLL J, LAI FA, AND SWANN K. (2004) Cell cycle-dependent $\mathrm{Ca}^{2+}$ oscillations in mouse embryos are regulated by nuclear targeting of PLC $\zeta$. J. Cell Science 117: 2513-2521

LAWRENCE,Y., WHITAKER,M. AND SWANN,K. (1997) Sperm-egg fusion is the prelude to the initial $\mathrm{Ca}^{2+}$ increase at fertilization in the mouse. Development 124: 223-241

LEE B, YOON SY AND FISSORE RA (2006) Regulation of fertilization-initiated $\left[\mathrm{Ca}^{2+}\right]$ i oscillations in mammalian eggs: a multi-pronged approach. Semin Cell Dev Biol. 17: 274-84.

MADGWICK S, LEVASSEUR M AND JONES KT (2005) Calmodulin-dependent protein kinase II, and not protein kinase $\mathrm{C}$, is sufficient for triggering cell-cycle resumption in mammalian eggs. J. Cell Science 118: 3849-3859

MADGWICK S, HANSEN DV, LEVASSEUR M, JACKSON PK AND JONES KT (2006) Mouse Emi2 is required to enter meiosis II by reestablishing cyclin B1 during interkinesis. J. Cel/ Biol. 174: 791-801

MARANGOS P AND CARROLL J (2004) Fertilization and InsP3-induced $\mathrm{Ca}^{2+}$ release stimulate a persistent increase in the rate of degradation of cyclin $B 1$ specifcally in mature mouse oocytes. Dev. Biol. 272: 26-38

MARKOULAKI, S., MATSON, S. AND DUCIBELLA, T. (2004) Fertilisation stimulates long lasting oscillations of CaMKII activity in mouse eggs. Dev. Biol. 272 : $15-25$

MATSON,S, MARKOULAKI S AND DUCIBELLA T. (2006) Antagonists of myosin light chain kinase and of myosin II inhibit specific events of egg activation in fertilized mouse eggs. Biol. Reprod. 74: 169-176

MATSU-URA T, MICHIKAWA T, INOUE T, MIYAWAI A, YOSHIDA M AND MIKOSHIBA K (2006) Cytosolic inositol 1,4,5-trisphophate dynamics during intracellular calcium oscillations in living cells. J Cel/ Biol. 173, 755-765

MCGUINNESS OM, MORETON RB, JOHNSON MH AND BERRIDGE MJ (1996) $A$ direct measurement of increases divalent cation influx in fertilised mouse oocytes. Development 122: 2199-2206

MCGINNIS LK, ALBERTINI DF AND KINSEY WH (2007) Localized activation of Src-family protein kinases in the mouse egg. Dev. Biol. 306: 241-254

MEHLMANN LM, CHATTOPADHYAY A, CARPENTER G, AND JAFFE LA. (2001) Evidence that phospholipase $C$ from the sperm is not responsible for initiating $\mathrm{Ca}^{2+}$ release at fertilization in mouse eggs. Dev. Biol. 236: 492-501

MEYER T AND STRYER L (1988) Molecular model for receptor stimulated calcium spiking. Proc. Natl. Acad. Sci. 85: 5051-5055

MIYAZAKI S, SHIRAKAWA H, NAKADA K, AND HONDA Y. (1993) Essential role of the inositol 1,4,5-trisphosphate/ $\mathrm{Ca}^{2+}$ release channel in $\mathrm{Ca}^{2+}$ waves and $\mathrm{Ca}^{2+}$ oscillations at fertilization of mammalian eggs. Deve/ Biol. 58: 62-78

NIXON VL AND JONES KT (2000) Sperm-induced Ca(2+) oscillations in mouse oocytes and eggs can be mimicked by photolysis of caged inositol 1,4,5trisphosphate: evidence to support a continuous low level production of inositol 1, 4,5-trisphosphate during mammalian fertilization. Dev. Biol. 225, 1-12

NIXON VL, LEVASSUER M, MCDOUGHALL A AND JONES KT (2002) $\mathrm{Ca}\left({ }^{2+}\right.$ ) oscillations promote APC/C-dependent cyclin B1 degradation during metaphase arrest and completion of meiosis in fertilizing mouse eggs. Curr Biol. 12: 74650.

NOMIKOS M, MULGREW-NESBITT A, PALLAVI P, MIHALYNE G, ZAITSEVA I, SWANN K, LAI FA, MURRAY D AND MCLAUGHLIN S (2007) Binding of phosphoinositid-specific phospholipase Czeta (PLCд) to phospholipid membranes. J. Biol. Chem. 282: 16644-16653

NOMIKOS, M., BLAYNEY, L.M., LARMAN, M.G., CAMPBELL, K., ROSSBACH, A. SAUNDERS, C.M., SWANN,K. AND LAI, F.A. (2005) Role of phospholipase C\{zeta\} domains in $\mathrm{Ca}^{2+}$-dependent phosphatidylinositol 4,5-bisphosphate hy- 
drolysis and cytoplasmic Ca ${ }^{2+}$ oscillations. J. Biol. Chem. 280: 31011-31018.

OANCEA E AND MEYER T (1998) Protein kinase C as a molecular machine for decoding calcium and diacylglycerol signals. Ce//95: 307-318

OZIL JP, AND HUNEAU D. (2001) Activation of rabbit oocytes: the impact of the $\mathrm{Ca}^{2+}$ signal regime on development. Development 128: 917-28

OZIL,J.P. AND SWANN,K. (1995) Stimulation of repetitive calcium transients in mouse eggs. Journal of Physiology 483: 331-346

OZIL JP, MARKOULAKI,S., TOTH S, MATSON S, BANREZES B., KNOTT JG, SCHULTZ RM, HUNAEU D AND DUCIBELLA T. (2005) Egg activation events are regulated by the duration of a sustained $\left[\mathrm{Ca}^{2+}\right]_{\text {cyt }}$ signal in the mouse. Dev. Biol. 282: 39-54

OZIL JP, BANREZES B, TOTH S, PAN H AND SCHULTZ RM (2006) $\mathrm{Ca}^{2+}$ oscillatory pattern in fertilized mouse eggs affects gene expression and development to term. Dev. Biol. 300: 534-544

PAGE BALUCH D, KOENEMAN BA, HATCH KR, MCGUAGHEY RW AND CAPCO DG (2004) PKC isotypes in post-activated and fertilized mouse eggs: association with the meiotic spindle. Dev. Biol. 274: 45-55

POLITI A, GASPERS LD, THOMAS AP AND HOFER T. (2006) Models of IP3 and $\mathrm{Ca}^{2+}$ oscillations: Frequency encoding and identification of underlying feedbacks. Biophys. J. 90: 3120-3133

RUNFT LL, JAFFE LA, AND MEHLMANN LM (2002) Egg activation at fertilization: where it all begins. Deve/ Biol. 245: 237-254

RICE A, PARRINGTON J, JONES KT, AND SWANN K. (2000) Mammalian sperm contain a $\mathrm{Ca}^{2+}$ sensitive phospholipase $\mathrm{C}$ activity that can generate $\operatorname{lns}_{3}$ from $\mathrm{PIP}_{2}$ associated with intracellular organelles. Deve/ Biol. 227: 125-135

REBECCHI MJ AND PENTYALA SN (2000) Structure, function, and control of phosphoinositide-specific phospholipase C. Physiol Rev. 80: 291-335.

RIDGWAY EB, GILKEY JC AND JAFFE, LF (1977) Free calcium increases explosively in activating medaka eggs Proc. Natl. Acad. Sci. 74: 623-627

ROGERS, N.T., HALET, G., PIAO,Y., CARROLL, J., KO, M.S.H. AND SWANN, K. (2006) The absence of a $\mathrm{Ca}^{2+}$ signal during mouse egg activation can affect parthenogenetic preimplantation development, gene expression patterns, and blastocyst quality. Reproduction 132: 45-57

RUNFT LL, JAFFE LA AND MEHLMANN LM (2002) Egg activation at fertilization: where it all begins. Dev. Biol. 245: 237-254

SAUNDERS CM, LARMAN MG, PARRINGTON J, COX LJ, ROYSEJ, BLAYNEY LM, SWANN K, AND LAI FA (2002) PLC $\zeta$ : a sperm-specific trigger of $\mathrm{Ca}^{2+}$ oscillations in eggs and embryo development. Development 129: 3533-3544.

SAUNDERS CM, SWANN K AND LAI FA (2007) PLCzeta, a sperm specifc PLC and it potential role in fertilization. Biochem. Soc. Symp. 74: 23-26

SNEYD J, TSANEVA-ATANASOVA K, REZNIKOV V, BAI Y, SANDERSON MJ AND YULE DI (2006) A method for determining the dependence of calcium oscillations on inositol trisphosphate oscillations. Proc. Natl. Acad Sci. 103: 1675-1680

SHIRAKAWA H, ITO M, SATO M, UEZAWA Y AND MIYAZAKI S. (2006) Measurement of intracellular IP3 during $\mathrm{Ca}^{2+}$ oscillations in mouse eggs with GFP based FRET probe. Biochem. Biophys. Res. Comm. 345: 781-788
STEINHARDT,R.A., EPEL,D., CARROLL,E.J. AND YANAGIMACHI,R. (1974) Is calcium ionophore a universal activator for unfertilised eggs. Nature 252: 41-43

STEINHARDT,R.A., ZUCKER,R. AND SCHATTEN, G. (1977) Intracellular calcium release at fertilization in the sea urchin egg. Dev. Biol. 58: 185-196

STRICKER SA. (1999) Comparative biology of calcium signaling during fertilization and egg activation in animals. Dev. Biol. 211: 157-76

SWANN K. (1990) A cytosolic sperm factor stimulates repetitive calcium increases and mimics fertilization in hamster oocytes. Development 110: 1295-1302

SWANN K (1994) Ca2+oscillations and sensitization of Ca2+ release in unfertilized eggs injected with a sperm factor. Cel/ Calcium 15; 331-339

SWANN, K., IGUSA, Y. AND MIYAZAKI, S. (1989) Evidence for an inhibitory effect of protein kinase $C$ on $\mathrm{G}$-protein mediated repetitive calcium transients in hamster eggs. EMBO J. 8: pp 3711-3781

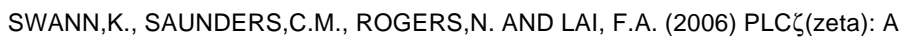
sperm protein that triggers $\mathrm{Ca}^{2+}$ oscillations and egg activation in mammals. Sem. Cell Dev. Biol. 17: 264-73

TATONE C, DELLE MONARCHE S, FRANCIONE A, GIOIA L, BARBONI B AND COLONNA R (2003) $\mathrm{Ca}^{2+}$-independent protein kinase $C$ signalling in mouse eggs during the early phases of fertilization. Int. J. Dev. Biol. 47: 327-33.

TOTH S, HUNEAU D, BANREZEES B AND OZIL JP (2006) Egg activation si the result of signal summation in the mouse. Reproduction 131:27-34

VAN BLERKOM J, DAVIS PW AND LEE J (1995) ATP content of human oocytes and developmental potential and outcome after in-vitro fertilization and embryo transfer. Human Reprod. 10: 415-424

WHITAKER, M. (2006) Calcium at fertilization and in early development. Physiol. Rev. 86: 25-88

WHITAKER M AND IRVINE RF (1983) Inositol 14,5-trisphophate microinjection activates sea urchin eggs. Nature 312: 636-639

WU H, SMYTH J, LUZZI V, FUKAMI K, TAKENAWA T, BLACK SL, ALLBRITTON NL AND FISSORE RA (2001) Sperm factor induces intracellular free calcium oscillations by stimulating the phosphoinositide pathway. Biol. Reprod. 64: 1338-1349

XU Z, WILLIAMS CJ, KOPF GS AND SCHULTZ RM (2003) Maturation associated increase in IP3 receptor subtype 1: role in conferring increased IP3 sensitivity and $\mathrm{Ca}^{2+}$ oscillatory behaviour in mouse eggs. Dev. Biol. 254: 163-171

YODA A, ODA S, SHIKANO T, KOUCKI Z, AWAJI T, SHIRAKAWA H, KINOSHITA K AND MIYAZAKI S (2004) $\mathrm{Ca}^{2+}$ oscillation-inducing phospholipase $\mathrm{C}$ zeta expressed in mouse eggs is accumulated to the pronucleus during egg activation. Dev. Biol. 268: 245-57.

YOON SY AND FISSORE RA (2007) Release of phospholipase C zeta and $\mathrm{Ca}^{2+}$ oscillation inducing activity during mammalian fertilization. Reproduction 134; 695-704

YOSHIDAN, AMANAI M, FUKIUT, KAJIKAWA E, BRAHMAJOSYULA M, IWAHORI A, NAKANO Y, SHOJI S, DIEBOLD J, HESSEL H, HUSS R AND PERRY AC (2007) Broad, ectopic expression of the sperm protein PLCZ1 induces parthenogenesis and ovarian tumours in mice. Development 134: 3941-52. 


\section{Related, previously published Int. J. Dev. Biol. articles}

See our recent Special Issue Developmental Biology in Poland edited by Tarkowski, Maleszewski and Kloc at:

http://www.ijdb.ehu.es/web/contents.php?vol=52\&issue=2-3

See our recent Special Issue Ear Development edited by Fernando Giraldez and Bernd Fritzsch at:

http://www.ijdb.ehu.es/web/contents.php?vol=51\&issue=6-7

Regionalized calcium signaling in zebrafish fertilization

Dipika Sharma and William H. Kinsey

Int. J. Dev. Biol. (2008) 52: 561-570

Defective calcium release during in vitro fertilization of maturing oocytes of LT/Sv mice

Karolina Archacka, Anna Ajduk, Pawel Pomorski, Katarzyna Szczepanska, Marek Maleszewski and Maria A. Ciemerych

Int. J. Dev. Biol. (2008) 52: doi: 10.1387/ijdb.072397ka

Ca2+-independent protein kinase $\mathbf{C}$ signalling in mouse eggs during the early phases of fertilization.

Carla Tatone, Simona Delle Monache, Antonella Francione, Luisa Gioia, Barbara Barboni and Rosella Colonna

Int. J. Dev. Biol. (2003) 47: 327-333

CpZPC, a newt ZPC molecule, localizes to the inner surface of the egg envelope.

Youko Makabe-Kobayashi, Etsuko Kudaira, Akihiko Watanabe and Kazuo Onitake

Int. J. Dev. Biol. (2003) 47: 51-58

Association of egg zona pellucida glycoprotein mZP3 with sperm protein sp56 during fertilization in mice.

$\mathrm{N}$ Cohen and $\mathrm{P} M$ Wassarman

Int. J. Dev. Biol. (2001) 45: 569-576

Fertilization triggers activation of Fyn kinase in the zebrafish egg.

W Wu and W H Kinsey

Int. J. Dev. Biol. (2000) 44: 837-841

Sperm-egg interaction at fertilization: glycans as recognition signals. F Rosati, A Capone, C D Giovampaola, C Brettoni and R Focarelli Int. J. Dev. Biol. (2000) 44: 609-618

A two-component cytoskeletal system of Xenopus laevis egg cortex: concept of its contractility.

L V Ryabova and S G Vassetzky

Int. J. Dev. Biol. (1997) 41: 843-851

Electrically fused-egg induction and its development in the goldfish, Carassius auratus.

E Yamaha and F Yamazaki

Int. J. Dev. Biol. (1993) 37: 291-298

Calcium in sea urchin egg during fertilization.

I Gillot, P Payan, J P Girard and C Sardet

Int. J. Dev. Biol. (1990) 34: 117-125

2006 ISI ${ }^{* *}$ Impact Factor $=3.577^{\star *}$

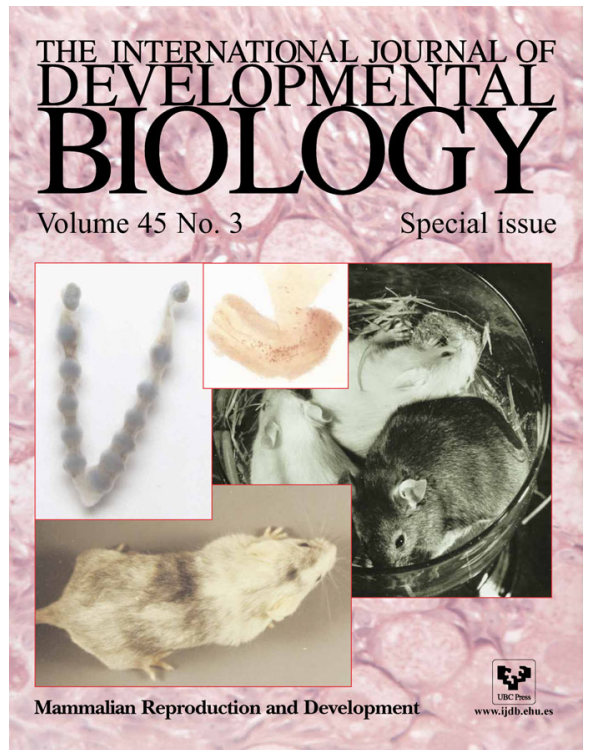

